\title{
Evaluation of producer organisations in the fruit and vegetable sector: Experiences from Hungary and Belgium
}

\author{
Felföldi, J. ${ }^{1}$, Molnár, A. ${ }^{2} \&$ Gellynck, X. ${ }^{2}$ \\ ${ }^{\prime}$ Department of Farm Business Management, Faculty of Agricultural Economics and Rural Development, \\ Centre for Agricultural Sciences, University of Debrecen 138 Böszörményi St ., H-4032 Debrecen \\ ${ }^{2}$ Department Agricultural Economics, Division Agro-food Marketing, Faculty of Bioscience Engineering, \\ Ghent University 653 Coupure Links, B-9000 Gent (Belgium)
}

\begin{abstract}
Summary: This paper focuses on the Producer Organisations (POs) in the fruit and vegetable sector in Hungary and in Belgium. Findings are drawn from a survey among members and leaders of POs. The aim of the research is to evaluate the operation of the Hungarian POs and to compare the results with the Flemish ones based on the perception of the respondents. We mark out from the research results that Hungarian PO members and PO leaders' perception significantly different in the following constructs: satisfaction with the CMO, environmental friendly production and willingness to cooperate. The most important difference between Hungarian and Flemish respondents was about the willingness to cooperate, and about the innovations in trading activities.
\end{abstract}

Key words: Producer Organisations (POs), Hungary, Belgium, fruit and vegetable sector, satisfaction

\section{Introduction and Research Objectives}

In the European Union (EU), the production and the sales of fruit and vegetables are regulated by the Common Market Organisation (CMO). The CMO was initiated in 1972 based on the 1035/72 Regulation and replaced by Regulation 2200/96 in 1997. CMO for fruits and vegetables aimed at making the sector more responsive to market trends rather than at the disposal of structural surpluses (Committee on Commodity Problems, 1998).

In the Regulation 2200/96, Producer Organizations (POs) become the key elements in the CMO for fruit and vegetable products. Every PO must submit an Operational Programme (OP) financed by an operational fund in order to be recognised by the EU $(M A F F, 2000)$. OPs must comply with EU requirements and objectives such as supply and price management, marketing programs, quality improvement and promoting environment-friendly production methods (Foreign Agricultural Service, 2003). OPs are financed through an operational fund, an account set up by the PO to hold contributions from its members based on the volume or value of products the PO is recognized for. The EU's financial contribution is paid directly into the PO's operational fund at the rate of 50 percent of the PO's actual expenditure with a maximum of 4.1 percent of the production value. A PO can also use its operational fund to top up EU withdrawal payments or to pay withdrawal compensation for products, which are not covered by the regulation originally $(E C$, 2003a; EC; 2003b; EC, 2003c; European Commission, 1996).

The aim of an operational programme is to improve the PO's performance and marketing skills, product quality and environmental considerations. The programme will comprise a number of elements, some of which are compulsory, aimed at improving the business while employing environmentally sound cultivation practices and the management of waste materials. The programme should be regarded as an important part of the POs business plan. Apart from the obvious benefit of EU funding, recognition of a PO with a successful OP is likely to lead to better co-operation between individual growers, a stronger market presence, better product quality, more environmentally friendly practices and an enhanced business performance. Consequently, when POs are able to set up a successful OP and implement it, a better market position, and more satisfied producers are probably to be obtained. The main elements of the OPs are the following: Production Planning, Trading Activities, Quality Control, Research Activities, Promotional Activities, Extension Service, Environmental Friendly Production, and Intervention. In the research we aimed to evaluate these areas from the producers' point of view.

POs can choose between different organisational structures and legal forms (Felföldi, 2005). They can even switch from one form to another during operation. As an example, in the Netherlands, a number of large agricultural cooperatives has been transformed recently into a limited liability company (Ltd) or a Public liability company (Plc), and the association has become a holding company, usually being the $100 \%$ shareholder of the limited company (Van der Sangen, 2001). Based on the organisational form the leaders of the POs, the CEOs, can be also members of it at the same time. As we assume huge differences between the perception of the CEOs and the ordinary producers, we make a 
distinction between both groups in our research. We define PO-leaders those respondents who participate in governing and managing the PO and we define PO-members those respondents not actively participating in management.

* In the different member states of the EU a great heterogeneity can be observed related to the integration level in the fruit and vegetable sector. The Hungarian fruit and vegetable sector, is characterised by a lack of integration between production and sales and the present forms of integration (e.g. POs) are not working properly apart from a few examples. Consequently, producers cannot aggregate the supply of the fruit and vegetable sector and cannot obtain a good bargaining position as compared to the concentrated retail sector. Contrary to this, the Belgian fruit and vegetable sector is characterised by about $70 \%$ integration and with this rate Belgium leads the field in Europe (Felföldi, 2005). In Belgium, it is important to highlight the Flemish region, where POs integrate 17.200 producers and $70 \%$ of the whole fruit and vegetable production is sold through POs (Guy, 2003; Guy, 2003a; Guy, 2003b; Administratie voor het Landbouwbeleid, 2003).

As a result, we consider the Flemish part of Belgium being a good base for investigating POs. Comparing experiences between Flanders and Hungary (taking into consideration the specificities of each country) can help Hungary to find solutions for the problems with the POs and can find the way for improvements.

The objective of the research is to assess the perception of the PO leaders and PO members about the different areas of PO operation. We aim to assess whether there were any significant differences in perceptions between PO leaders and PO members in Hungary on the one hand and between respondents from Hungary and Flanders on the other.

\section{Research Methodology}

First, the EU regulations were analysed in connections with the fruit and vegetable sector. Secondly, we consulted books, articles published in farmers' journals and articles published in conference proceedings in connection with the fruit and vegetable sector and the POs. We considered the farmers' journals as a very important source of acquiring information about the producers' perception in connection with POs and the CMO. Some special case studies we gained from the Hungarian Fruit and Vegetable Board, from the different interbranch organisations in the Hungarian and Belgian fruit and vegetable sector, from the European Commission, from the Ministry of the Flemish Community (Administration for the Agricultural Policy) and from the POs. In Flanders, one of the biggest PO (REO VEILING) was visited, and an in-depth interview was conducted with the CEO in order to gain better understanding about the characteristics of the Flemish PO operation.

Finaly, an electronic database was set up consisting of all the collected informations and data. It was used as a base to compare our findings with the present state of art in literature.
Next, a short description of the research design, sample, scales, and reliability are presented.

\section{Research design}

Data were collected by means of a survey among PO members and PO leaders in Hungary and in Flanders during the period 2002-2003. In Flanders, the Ministry of the Flemish Community (Administration for the Agricultural Policy) carried out the research,. The aim of the Flemish Community was to investigate the effects of the Regulation $2200 / 96$ for the fruit and vegetable sector from the producers' point of view.

\section{Sample}

In Flanders, the total population comprised 16 POs in the fruit and vegetable sector in 2003 and 205 questionnaires were sent to $15 \mathrm{POs}$ by post. In total 61 respondents completed and returned the questionnaire, which results in a response rate of about $30 \%$. In Hungary, 105 questionnaires were analysed. Through personal interviewing, $60 \%$ of the questionnaires were completed. These interviews were conducted during the PO workshop (29 $9^{\text {th }}$ October 2004) organised by the Hungarian Fruit and Vegetable Board and the Foodapest (Food, Drink and Food Processing Industry Trade Fair, 24 $4^{\text {th }}$ November 2004).

The rest of the questionnaires were completed through the help of the PO leaders, who distributed the questionnaires among the members of the POs.

\section{Scales}

As we aimed to compare Flemish findings with Hungarian ones, we used in the Hungarian study the same questionnaire as in Flanders. In the questionnaire respondents had to evaluate statements about the EU regulation and about the different operational areas of the PO. The statements were measured through 5 point Likert scales varying from -2 to 2 , whereas -2 means 'I completely disagree', -1 means 'I disagree', 0 means that 'I have no opinion', 1 means 'I agree' and 2 means 'I completely agree with the statement'. We also provided the possibility for comments next to each statement in order to obtain a clearer view about respondents' perception.

One part of the questionnaire was created in the way that multiple items were developed to measure several constructs (Table 1.): awareness, satisfaction with $\mathrm{CMO}$, satisfaction with $\mathrm{PO}$, innovation in trading activities, importance of research activities, environmental friendly production, importance of intervention, willingness to cooperate, democratic governance system). The other part of the questionnaire contains two topics measured through several single items. Because of the single item format, these measures have limited reliability. Although, these single items were also grouped into 2 general topics: production planning and trading activities (Table 3 ). The trading activity 
topic result in a better understanding of the construct "innovation in trading activities" and provide additional information.

\section{Reliability}

An important aspect of reliability relates to the degree of internal consistency, or degree of inter-correlation among several measures for the same construct. Cronbach's alpha coefficient was used to assess the degree of internal consistency within each particular construct. In general, alpha values of 0,7 or higher are considered to be acceptable, with 0,6 being acceptable for new scales (Churchill, 1979). All scales exceeded this threshold (Table 1). In case of the construct "Satisfaction with CMO" one variable had to be recoded before the analysis (marked with an asterisk). Measuring the same construct, but being negatively worded, the variable directs in the opposite direction.

Table 1. Descriptive and reliability data for constructs

\begin{tabular}{|c|c|c|}
\hline & Mean & Cronbach's Alpha \\
\hline Awareness & 0,78 & 0,71 \\
\hline I know what the $\mathrm{CMO}$ is & 1,20 & \\
\hline 1 know the direct advantages of the CMO & 0,47 & \\
\hline I know what the OP is & 0,97 & \\
\hline I know the the contents of OP of my PO & 0.97 & \\
\hline I am aware of the results of the research conducted by the PO & 0,30 & \\
\hline Satisfaction with CMO & 0,37 & 0,78 \\
\hline $\mathrm{CMO}$ is a good opportunity for the fruit and vegetable sector & 0,90 & \\
\hline CMO is a good opportunity for producers & 0,93 & \\
\hline The advantages of the $\mathrm{CMO}$ are too incomprehensible * & $-0,07$ & \\
\hline I am satisfied with the fact that the costs of the sales have declined after introducing the CMO & $-0,30$ & \\
\hline Satisfaction with PO & 0,64 & 0,88 \\
\hline It is more advantageous for me to be the member of the PO, than not to & 0,77 & \\
\hline I am well informed through my PO about all the relevant questions in connection with my farming & 0,53 & \\
\hline PO-membership has a positiv imapct on my individual farming & 0,47 & \\
\hline POs have very important role in aggregating the supply in the sector & 0,80 & \\
\hline The OP of my PO is good & 0,63 & \\
\hline Innovation in trading activities & 1,48 & 0,76 \\
\hline My PO should find new, modern sales methods & 1,47 & \\
\hline PO have to develop a more active trading system in order to be successfull & 1,50 & \\
\hline Importance of research activities & 1,63 & 0,78 \\
\hline Research activities are very important part of the $\mathrm{OP}$ & 0,73 & \\
\hline The research activities in OP are important and achievable & 0,90 & \\
\hline Environmental friendly production & 3,33 & 0,76 \\
\hline Consumers are aware of environmentally friendly production methods & $-0,23$ & \\
\hline Consumers favour environmental friendly products & 0,33 & \\
\hline Environmental friendly production strenghten the bargaining position of the producers & 0,50 & \\
\hline Environmental friendly production is very important and everybody should condsider it during farming & 1,37 & \\
\hline Environmental friendly production should be extended and more research should be carried out about it & 1,37 & \\
\hline Importance of intervention & 0,72 & 0,77 \\
\hline Intervention is very important to maintain market prices & 0,43 & \\
\hline Intervention should be extended for other products and the PO should cover it through the OP & 1,00 & \\
\hline Willingness to cooperate & 1,30 & 0,72 \\
\hline PO should cooperate with other POs in trading activities & 2,37 & \\
\hline The PO should cooperate with other POs in research & 2,87 & \\
\hline PO should cooperate with other POs in Promotional Activities & 2,57 & \\
\hline Democratic governance system & 0,42 & 0,90 \\
\hline I participate in writing the $\mathrm{OP}$ & 0,30 & $\therefore$ \\
\hline In my PO there is a democratic decision-making system & 0,50 & \\
\hline I feel involved in the decision-making process of the PO & 0,47 & \\
\hline
\end{tabular}

Note: Five-point Likert scale varying from -2 to 2 


\section{Analysis and findings}

\section{Comparison based on the constructs}

The analysis of the collected data involved multivariate statistical analysis implemented in the software SPSS 12.0 for Windows (Statistical Package for the Social Sciences).

The analysis was conducted in several steps. First we investigate the 9 constructs and present the research findings along these constructs. In this part first, we look for significant differences between the Hungarian PO-leaders and the PO-members and next between Hungary and Flanders. As it was mentioned above, findings from investigating the construct "innovation in trading activities" can be amended by the research findings from the "trading activities" general topic. Finally, there is still 1 general topic for investigation. This is about the production planning of the POs.

To test for differences between the PO-leaders and POmembers in Hungary, the mean results are computed by applying the independent-sample t-test, a statistical test designed to measure mean differences of test scores between small samples. The significant differences are reported at the 5 percent level of significance for a two-tailed test.

To test for differences between the Hungarian and the Flemish respondents we couldn't use independent-sample ttest, as we didn't have the database of the responses from the Flanders. Consequently, as we only have the mean scores and the concluded research results, we used one-sample t-test to compare means for the statements. Statistical results for the one-sample t-test are presented in Table 2.

Significant differences between Hungarian PO-leaders and $\mathrm{PO}$-members in satisfaction with $\mathrm{CMO}$, in environmental friendly production and in willingness to cooperate are noticed. In order to explain these differences, we investigated the items of the constructs one by one. It is a rather surprising result that PO leaders have lower scores evaluating the $\mathrm{CMO}$ as a good opportunity for the fruit and vegetable producers. Consequently, the significant difference between the leaders and the members in satisfaction about the CMO is caused by the fact that, $\mathrm{PO}$-leaders find the advantages of the $\mathrm{CMO}$ rather too incomprehensible and they don't really think that the CMO is a good opportunity for the producers.

From the comments given by the respondents we may conclude that although a lot of advantages of the CMO are perceived, these advantages do not directly reach the producers. As the aims of the $\mathrm{CMO}$ are to enable producers to enter EU markets, to increase the quality of the products, to gear supply and demand to one another, these aims can be reached only in the long run. Consequently, the advantages of the CMO are perceived as an indirect thing. The low fruit and vegetable prices experienced in the last years compared to previous years can also be the reason why the leaders don't see the advantages of the CMO. CMO cannot dissolve conflicts in the market immediately. It needs time, and consequently it is rather indirectly and not directly helps the producers and the POs.
Investigating the construct of environmental friendly production learns that $\mathrm{PO}$ leaders perceive less possible advantages of the environmental friendly production as compared to PO members. The leaders score again a surprising result, as they find it rather difficult to obtain a better market position as a result of selling environmental friendly products. The significant differences between the members and the leaders relate to the fact that PO leaders have to find effective demand for the products and have to sell them on a relatively higher prices compared to conventional products. Leaders find consumers not being aware and not in favour of environmental friendly products. From the additional comments we concluded that Hungarian POs don't work for so long, and they have only a few year experiences on the market. They might not start to build up a strategy for differentiating themselves by selling environmental friendly products. As a result, because of the lack of practise, PO leaders at the moment find it difficult to strengthen the position of the producers or the POs through selling environmentally friendly products.

$\mathrm{PO}$ leaders and PO members differ significantly in their willingness to cooperate with other POs. PO leaders have statistically higher scores in willingness to cooperate in promotional activities and in research activities with other POs. As they are the direct managers of the PO, they might have regular contact with other POs and consequently they could more easily estimate a possible cooperation. Although PO members are not against cooperation, scores are significantly lower. As a result of bad experiences from the past (when producers were pushed to cooperate during communism) PO members are not that enthusiastic about new forms of cooperation. From the comments we could conclude that first they want a successfully operating PO, and afterwards, they might want to further integrate themselves. From the leaders point of view, as they are responsible for carrying out research and promotional activities, they are willing to share the high costs involved with other POs and do not mind to share the benefits as well. As e.g. research activities rather indirectly effect the daily operation of the PO, leaders do not find it impossible to carry out such activities even with competitors. According to the literature, and based on examples from the EU, higher level of cooperation among POs can lead to success, but is not the only way for the future. In some European countries, there are a lot of POs who decide not to take any initiative and not to participate in cooperation among POs. This is the sole responsibility of the organisation (Felföldi, 2005).

Separate statistical tests (one-sample t test) were applied to the results of Flanders for comparison purposes. As shown in Table 2 significant differences are identified between the two groups for the "innovation in trading activities" and "willingness to cooperate".

Focusing on the perception of the Hungarian and Belgian related to innovations in trading activities, we conclude that Flemish respondents are more innovative in applying different sales methods. From the respondents comments we concluded that they perceive the trading activities of the PO to be good and working successfully, but they are open for 
Table 2. Statistics for the respondents in the different constructs

\begin{tabular}{|c|c|c|c|c|c|c|c|c|}
\hline & $\begin{array}{c}\text { Mean } \\
\text { HU }\end{array}$ & $\begin{array}{c}\text { Mean } \\
\text { Leaders } \\
\text { HU }\end{array}$ & $\begin{array}{c}\text { Mean } \\
\text { Members } \\
\text { HU }\end{array}$ & $\begin{array}{c}\text { t-test for } \\
\text { Equality } \\
\text { of } \\
\text { Mean }\end{array}$ & $\begin{array}{c}\text { Sig. } \\
(2- \\
\text { tailed) }\end{array}$ & $\begin{array}{c}\text { Mean } \\
\text { Flanders }\end{array}$ & $\mathrm{t}$ & $\begin{array}{l}\text { Sig. } \\
\text { (2-tailed) }\end{array}$ \\
\hline Awareness & 0.78 & 0.88 & 0.73 & 0.59 & 0.56 & 0.63 & 1.27 & 0.21 \\
\hline I know what the $\mathrm{CMO}$ is & 1.20 & 1.30 & 1.15 & & & 1.11 & & \\
\hline I know the direct advantages of the $\mathrm{CMO}$ & 0.47 & 0.10 & 0.65 & & & 0.49 & & \\
\hline I know what the OP is & 0.97 & 1.40 & 0.75 & & & 0.72 & & \\
\hline I know the the contents of OP of my PO & 0.97 & 1.20 & 0.85 & & & 0.73 & & \\
\hline I am aware of the results of the research conducted by the PO & 0.30 & 0.40 & 0.25 & & & 0.10 & & \\
\hline Satisfaction with CMO & 0.37 & -0.25 & 0.68 & -2.92 & $\underline{0.01}$ & 0.53 & -0.97 & 0.34 \\
\hline $\mathrm{CMO}$ is a good opportunity for the fruit and vegetable sector & 0.90 & 0.40 & 1.15 & -1.49 & 0.16 & 0.88 & & \\
\hline $\mathrm{CMO}$ is a good opportunity for producers & 0.93 & 0.30 & 1.25 & -2.11 & 0.04 & 0.75 & & \\
\hline The advantages of the $\mathrm{CMO}$ are too incomprehensible * & -0.07 & -0.80 & -0.05 & -2.65 & 0.01 & -0.11 & & \\
\hline $\begin{array}{l}\text { I am satisfied with the fact that the costs of the sales have declined after } \\
\text { introducing the CMO }\end{array}$ & -0.30 & -0.90 & 0.35 & -1.92 & 0.07 & 0.58 & & \\
\hline Satisfaction with PO & 0.64 & 0.54 & 0.69 & -0.41 & 0.68 & 0.83 & -1.13 & 0.27 \\
\hline It is more advantageous for me to be the member of the PO, than not to & 0.77 & 0.80 & 0.75 & & & 1.11 & & \\
\hline $\begin{array}{l}\text { I am well informed through my PO about all the relevant questions in } \\
\text { connection with my farming }\end{array}$ & 0.53 & 0.40 & 0.60 & & & 0.80 & & \\
\hline PO-membership has a positive impact on my individual farming & 0.47 & 0.40 & 0.50 & & & 0.67 & & \\
\hline POs have very important role in aggregating the supply in the sector & 0.80 & 0.40 & 1.00 & & & 1.03 & & \\
\hline The OP of my PO is good & 0.63 & 0.70 & 0.60 & & & 0.56 & & \\
\hline Innovation in trading activities & 1.48 & 1.40 & 1.53 & -0.49 & 0.63 & 0.29 & 11.58 & $\underline{0.00}$ \\
\hline My PO should find new. modern sales methods & 1.47 & 1.30 & 1.55 & & & 0.62 & 6.81 & 0.00 \\
\hline PO have to develop a more active trading system in order to be successfull & 1.50 & 1.50 & 1.50 & & & -0.05 & 14.83 & 0.00 \\
\hline Importance of research activities & 1.63 & 0.80 & 0.83 & -0.10 & 0.92 & 0.68 & & \\
\hline Research activities are very important part of the OP & 0.73 & 1.00 & 0.85 & & & 0.84 & & \\
\hline The research activities in OP are important and achievable & 0.90 & 0.60 & 0.80 & & & 0.52 & & \\
\hline Environmental friendly production & 3.33 & 0.28 & 0.86 & -2.43 & 0.02 & 0.47 & 1.18 & 0.25 \\
\hline Consumers are aware of environmentally friendly production methods & -0.23 & -0.90 & 0.10 & -3.01 & 0.01 & -0.60 & & \\
\hline Consumers favour environmental friendly products & 0.33 & -0.40 & 0.70 & -2.72 & 0.01 & 0.86 & & \\
\hline $\begin{array}{l}\text { Environmental friendly production strenghten the bargaining position } \\
\text { of the producers }\end{array}$ & 0.50 & 0.00 & 0.75 & -2.10 & 0.04 & 0.91 & & \\
\hline $\begin{array}{l}\text { Environmental friendly production is very important and everybody should } \\
\text { condsider it during farming }\end{array}$ & 1.37 & 1.40 & 1.35 & 0.23 & 0.82 & 0.88 & & \\
\hline $\begin{array}{l}\text { Environmental friendly production should be extended and more research } \\
\text { should be carried out about it }\end{array}$ & 1.37 & 1.30 & 1.40 & -0.41 & 0.68 & 0.32 & & \\
\hline Importance of intervention & 0.72 & 0.70 & 0.73 & -0.09 & 0.93 & -0.22 & 1.61 & 0.12 \\
\hline Intervention is very important to maintain market prices & 0.43 & 1.00 & 1.00 & & & 0.03 & & \\
\hline $\begin{array}{l}\text { Intervention should be extended for other products and the PO should } \\
\text { cover it through the OP }\end{array}$ & 1.00 & 0.40 & 0.45 & & & -0.48 & & \\
\hline Willingness to cooperate & 1.30 & 1.67 & 1.12 & 2.90 & $\underline{0.01}$ & 0.97 & 7.30 & 0.00 \\
\hline PO should cooperate with other POs in trading activities & 1.53 & 1.70 & 1.45 & 1.29 & 0.21 & 0.78 & 8.13 & 0.00 \\
\hline The PO should cooperate with other POs in research & 1.03 & 1.60 & 0.75 & 3.09 & 0.00 & 1.03 & 0.02 & 0.98 \\
\hline PO should cooperate with other POs in Promotional Activities & 1.33 & 1.70 & 1.15 & 2.11 & 0.04 & 1.11 & 1.72 & 0.10 \\
\hline Democratic governance system & 0.42 & 0.93 & 0.17 & 1.92 & 0.06 & 0.51 & -0.45 & 0.66 \\
\hline I participate in writing the OP & 0.30 & 0.90 & 0.00 & & & 0.21 & & \\
\hline In my PO there is a democratic decision-making system & 0.50 & 1.00 & 0.25 & & & 0.59 & & \\
\hline I feel involved in the decision-making process of the PO & 0.47 & 0.90 & 0.25 & & & 0.73 & & \\
\hline
\end{tabular}


new, modern sales methods as well. Besides auction sales (clock sales), applied for more than 4 decades in Flanders, Flemish respondents approved to use tools such as contracts, seasonal sales, internet sales. Flemish respondents commented that the consumer oriented market is experience a rapid change that the trading activities of the PO have to follow these changes, and have to always choose the best sales methods. According to Kiss et al. (2004) producers and POs can choose among different sales methods, but after choosing one, it takes a lot of extra cost to switch. Consequently, it is extremely important to find the most appropriate sales technique, which suit the PO the most.

A similar comparison was made for examination of the willingness of the respondents to cooperate. As shown in Table 2. significant difference between the Hungarian and Flemish respondents. Flemish respondents get lower mean scores for the construct, although in that region, there are already integration and cooperation among POs on the second, moreover third level. POs in cooperation on the second level can write and implement an OP together and carry out common promotional activities, quality control system and trading activities. It is rather surprising that in a region like Flanders, with several well operating cooperation among POs, the respondents get lower scores than in Hungary. As a possible reason, we investigated that in Hungary, the whole PO system is new, and the first POs were created after the 2200/96 Regulation. Contrary to this, in Belgium, most of the POs have a 30-50 year old operational experience. Considering this difference between the two countries we concluded from the research that Hungarian POs are willing to cooperate in several fields very actively, but besides we also know that, this is not the case yet.

\section{Comparison based Production Planning and Trading Activities}

A similar comparison between the leaders and members and between the Hungarian and Flemish respondents was made in the second part of the research, but now along 2 different topics.

From the Table 3, we could investigate 2 more topics in connection with the PO operations from the Hungarian and Flemish producers' point of view.

Focusing on production planning, there were several statements, which differ significantly among Hungarian and Flemish respondents. The EU regulations about POs claim that one of the tasks of the PO is to plan and organize the production of the members (FVM, 1999). As a result, it is quite important to investigate how the PO implements the planning of the production among members. According to Sántha et al. (1998), producers have to learn to accept the production planning ideas of the PO leaders, as in the long run, it is the only way to survive, to have efficient operation. and to create supply according to the needs of the market. Investigating the results we concluded that in Flanders, most of the producers want more freedom to decide what and how much to grow, but they follow the production rules of the PO hoping that it will lead to meeting the needs of the consumers and resulting in higher price.

There was a significant difference between the evaluation of the trading system in Hungary and in Flanders. Flemish respondents found the PO's trading system to be good and they didn't find the direct sales to consumers to be very important. One can imagine that in case of a well operating trading system in the PO, it is not necessary for the producers

Table 3. Statistics for the respondents about the different topies with single items

\begin{tabular}{|c|c|c|c|c|c|c|c|c|}
\hline & $\begin{array}{c}\text { Mean } \\
\text { HU }\end{array}$ & $\begin{array}{c}\text { Mean } \\
\text { Leaders } \\
\text { HU }\end{array}$ & $\begin{array}{c}\text { Mean } \\
\text { Members } \\
\text { HU }\end{array}$ & $\begin{array}{c}\text { t-test for } \\
\text { Equality } \\
\text { of } \\
\text { Mean }\end{array}$ & $\begin{array}{l}\text { Sig. } \\
(2- \\
\text { tailed) }\end{array}$ & $\begin{array}{c}\text { Mean } \\
\text { Flanders }\end{array}$ & t & $\begin{array}{l}\text { Sig. (2- } \\
\text { tailed) }\end{array}$ \\
\hline \multicolumn{9}{|l|}{ Production Planning } \\
\hline Every producer should have the possibility to produce what they want & -0.90 & -1.00 & -0.85 & -0.45 & 0.65 & 0.86 & -11.41 & 0.00 \\
\hline Every producer should have the possibility to produce as much as they want & -0.77 & -1.00 & -0.65 & -1.01 & 0.32 & 0.64 & -8.58 & 0.00 \\
\hline I think it is a good idea, if the PO tell me when to deliver the products to the PO & 0.93 & 1.30 & 0.75 & 1.61 & 0.12 & 0.55 & 2.31 & 0.03 \\
\hline The PO and the producers should decide together what to grow & 1.20 & 1.20 & 1.20 & 0.00 & 1.00 & -0.09 & 10.64 & 0.00 \\
\hline PO help me with organizing the delivery of the products & 0.57 & 0.50 & 0.60 & -0.28 & 0.78 & 0.50 & 0.41 & 0.69 \\
\hline \multicolumn{9}{|l|}{ Trading Activities } \\
\hline If the PO works efficiently. I will deliver $100 \%$ of my product there & 1.63 & 1.70 & 1.60 & 0.52 & 0.61 & 0.74 & 9.98 & 0.00 \\
\hline POs are necessary to compensate the concentration of the retail sector & 1.63 & 1.80 & 1.55 & 1.23 & 0.23 & 0.97 & 5.91 & 0.00 \\
\hline The auction system should be the most important sales technique in the PO & 0.17 & -0.30 & 0.40 & -1.25 & 0.23 & 0.44 & -1.21 & 0.23 \\
\hline Direct sales to consumers are very important & 0.73 & 0.90 & 0.65 & 0.49 & 0.63 & -0.35 & 4.52 & 0.00 \\
\hline The trading system of the PO is good & 0.10 & 0.10 & 0.10 & 0.00 & 1.00 & 0.62 & -2.40 & 0.02 \\
\hline The PO should be more active in export & 1.00 & 1.10 & 0.95 & 0.38 & 0.71 & -0.30 & 7.00 & 0.00 \\
\hline PO should continue the present export activities & 0.23 & 0.20 & 0.25 & -0.11 & 0.91 & 0.63 & -1.86 & 0.07 \\
\hline PO should look for new market possibilities & 1.60 & 1.70 & 1.55 & 0.68 & 0.50 & 1.07 & 5.15 & 0.00 \\
\hline $\begin{array}{l}\text { My PO should buy products from other sources during those periods, } \\
\text { when there is not enough products through the members } \\
\text { in order to keep the buyers loyal }\end{array}$ & 1.10 & 1.00 & 1.15 & -0.37 & 0.71 & 0.24 & 4.58 & 0.00 \\
\hline
\end{tabular}


to sell their products by themselves. Naturally, Flemish respondents consider the auction system as one of the most important sales method of the PO, while in Hungary (where there are no sales through auction) there were only a few respondents by the side of the auction system.

\section{Conclusion and Recommendations}

Hungarian PO members and PO leaders' perception significantly different in constructs: satisfaction with the $\mathrm{CMO}$, environmental friendly production and willingness to cooperate. In order to avoid having conflicts, because of this different perception the PO should focus more on these areas and strengthen the communication with the PO members in the same time.

The most important difference between Hungarian and Belgian respondents was about the willingness to cooperate, and about the innovations in trading activities, although we conclude that Flemish and Hungarian POs frequently has the same perception about the POs and face the same problems. In order to improve the efficiency of the commercial system, POs should keep looking for new sale possibilities.

Based on the present study the success and bottlenecks of the POs can be more easily understood and the problems of the operation can be solved more easily. Although, in order to confirm the results of the study, there is a need to carry out other research in this field.

\section{References}

Committee on Commodity Problems (1998): Report of the twelfth session of the intergovernmental group on citrus fruit. Valencia, Spain.

Churchill, G.A. (1979): A paradigm for developing better measures of marketing constructs. Journal of Marketing Research 162,64-73p
EC (1996): Council Regulation (EC) No 2200/96 of 28 October 1996 on the Common Organization of the Market in Fruit and Vegetables.

EC (2003a): A Bizottság 1432/2003/EK rendelete (2003, augusztus 11.) a 2200/96/EK tanácsi rendeletnek a termelöi szervezetek elismerésének feltételei és a termelöi csoportok elözetes elismerése tekintetében történö alkalmazására vonatkozó részletes szabályok megállapitásáról.

EC (2003b): A Bizottság 1433/2003/EK rendelete (2003. augusztus 11.) a mủködési alapok, a müködési programok és a pénzügyi hozzajajarulás tekintetében a 2200/96/EK tanácsi rendelet részletes alkalmazási szabályainak megállapitásáról.

EC (2003c): A Bizottság 1943/2003/EK rendelete (2003. november 3.) az elözetesen elismert termelöi csoportoknak nyújtott támogatás tekintetében a 2200/96/EK tanácsi rendelet alkalmazási szabályainak megállapitásáról.

Felföldi J. (2005): A TÉSZ-ek piaci szerepe. In: Felföldi Jảnos (szerk.), 2005. Termelöi értékesitö szervezetek (TÉSZ) a zöldséggyümölcs ágazatban. 34. p. Szaktudás Kiadó Hảz Budapest.

Foreign Agricultural Service (2003): GAIN Report, European Union Trade Policy Monitoring Fruit and Vegetables - EU Subsidies, 2003.

FVM (1999): FVM rendelet a zöldség-, gyümölcstermelöi, -értékesítỏ szervezetekröl. (25/1999. (III. 5.) FVM rendelet).

FVM (2003a): FVM rendelet a zöldség-gyümölcs termelöi értékesitö szervezeteket érintö nemzeti szabályozásról. (120/2003. (XII.02.) FVM rendelet).

Guy, L. (2003a): Evaluatie GMO-periode 1997 - 2003, Ministerie van de Vlaamse Gemeenschap, Administratie voor het Landbouwbeleid, Dienst Plantaardige Producten

Guy, L. (2003b): Resultaten GMO - enquête - 2003: Ministerie van de Vlaamse Gemeenschap, Dienst Plantaardige Producten.

Administratie voor het Landbouwbeleid (2003): Sporenbeleid voor de sector groenten en fruit - Lange termijnvisie en -strategie bij de invulling van de operationele programma's 2004-2008.

MAFF (2000): Processing and Marketing Grant. Introductory Booklet. Rural Development Programme, England

Z. Kiss L., Lacka S.né \& Papp J. (2004): A gyümölcságazat helyzete és versenyképessége a Csatlakozáskor. Kertgazdaság/ Magyar Mezögazdaság. 36. (1). 